\title{
SOWING THE STONE: SACRED GEOGRAPHY AND CULTURAL CONTINUITY. ECONOMY AMONG THE HIGHLAND MAYA OF GUATEMALA
}

\author{
LARS FRÜHSORGE \\ University of Hamburg
}

\begin{abstract}
The functions of Classic Maya stelae as political monuments and as containers for the "spiritual essence" of rulers are well known. In contrast, it has hardly been recognized that a similar ceremonial use of stones survived among the Highland Maya of Guatemala throughout the Postclassic and Colonial period into modern times. According to colonial sources the "souls" of deceased rulers were conserved in portable stones and guarded by high-ranking officials. Royal burial ceremonies included the erection of stone images representing the departed rulers as part of a sacred geography. Even among the modern Maya there is ritual featuring the "sowing" of a stone in a natural location which becomes linked to the life-force of a person. In a similar way different stone features - both natural and artificialcontinue to play a role in various ceremonies related to the economic well-being or the demarcation of territories between competing communities.
\end{abstract}

KEYwORDs: stela, ancestor worship, cultural continuity, Guatemala, sacred geography.

Resumen: Son bien conocidas las funciones de las estelas mayas como monumentos políticos y como "contenedores" para la "esencia espiritual" de los gobernantes. Por el contrario, casi no ha sido reconocido que un similar uso ceremonial similar de las piedras sobrevivió entre los mayas del altiplano de Guatemala a lo largo de los periodos Posclásico y Colonial hasta el presente. Según las fuentes coloniales, las "almas" de los gobernantes fallecidos se conservaban en piedras portátiles custodiadas por funcionarios especiales. Las ceremonias funerarias incluían la construcción de imágenes de piedra que representaban a los gobernantes difuntos como parte de una "geografía sagrada". Incluso entre los mayas actuales hay un ritual de "siembra" de una piedra en un lugar natural, que se vincula a la fuerza vital de una persona. De manera similar, diferentes clases de piedras (tanto naturales como artificiales) tienen un papel importante en diversas ceremonias relacionadas con el bienestar económico o la demarcación de los territorios de las comunidades mayas contemporáneas.

Palabras clave: estela, veneración a los antepasados, continuidad cultural, Guatemala, geografía sagrada.

RECEPCIÓN: 25 de noviembre de 2013.

ACEPTACIÓN: 25 de enero de 2014. 



\title{
SOWING THE STONE: SACRED GEOGRAPHY AND CULTURAL CONTINUITY. ECONOMY AMONG THE HIGHLAND MAYA OF GUATEMALA
}

\author{
LARS FRÜHSORGE \\ University of Hamburg
}

\section{Introduction}

Among the various artistic expressions of the ancient Maya, the stela is probably considered the most iconic symbol of their culture. Early descriptions, drawings and photographs of stelae produced by travelers such as Teobert Maler (1997), Frederik Catherwood and John Lloyd Stephens (1969) had a remarkable influence on the western image of Maya culture and stimulated a growing interest in North America and Europe which ultimately resulted in the emergence of Maya studies as an independent discipline. But what have we learned about these enigmatic and fascinating monuments so far?

Stelae are usually associated with the Classic Maya of the Southern Lowlands, but there are also several examples from Northern Yucatan and the Highlands of Guatemala which date both to the Preclassic and Postclassic. The multitude of stelae known from excavations, museums and private collections appear in different forms and sizes, some of them carved with images, some with texts or both. Others were painted or simply remained undecorated. There are also a number of different meanings which could have been attributed to these monuments:

Judging from their proximity to the temple-pyramids the stelae certainly served as markers of sacred space. Caches with offerings deposited during the dedication of these monuments might have even served to create such sacred spaces in the first place. Additionally the altars which are frequently associated with the stelae indicate that rituals must have taken place there rather frequently (figure 1). Ethnohistoric sources such as Diego de Landa's Relación de las cosas de Yucatán (1985) as well as inscriptions on many stelae confirm that their erection of these monuments was related to calendrical cycles. The close linguistic relation between the calendar and the stones is best illustrated by the fact that the term tun ("stone") has also the meaning of "year" and also appears in the word k'atun which refers to a period of 20 years. Obviously the stela could thus be interpreted as a representation of time itself. 


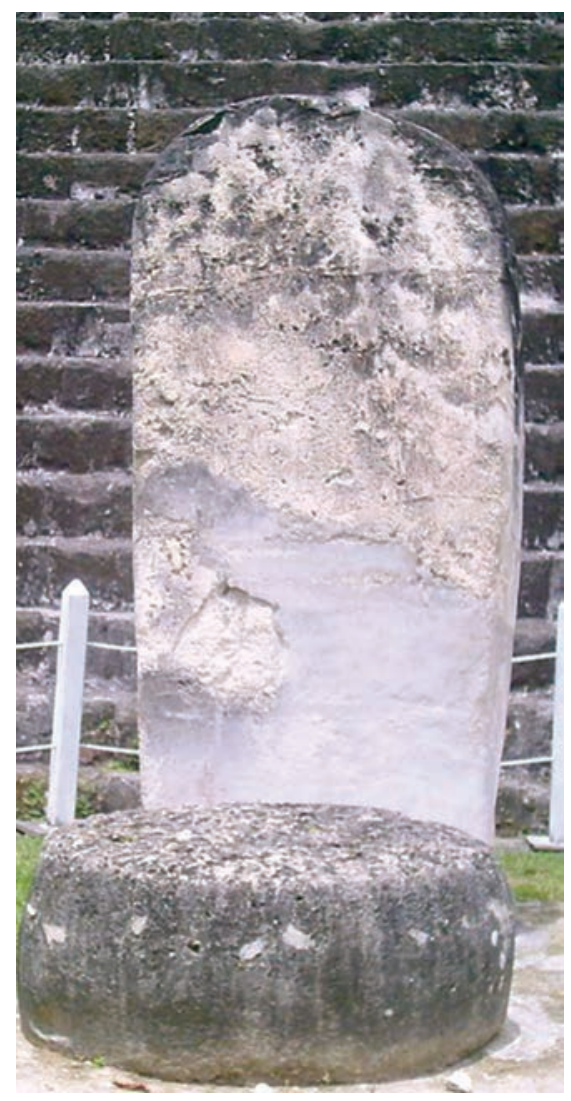

FIGURE 1. Stela with Altar, Tikal (Guatemala)

Especially the carved stelae with the images of rulers and the inscriptions commemorating their deeds must have served as sites of memory which helped to keep royal history alive in the minds of the people. Due to the dynastic nature of ancient Maya rulership, the stelae must have served both as symbols and sources of political power, which confirmed the legitimacy of the ruling lineage. In this context it is noteworthy that in instances of dynastic changes stelae of former rulers were sometimes relocated, damaged, or even used as filling material in the construction of new buildings (Martin and Grube, 2008: 29, 196).

However, most of these monuments remained in their original place for centuries and - as the elaborate altars indicate — rituals were constantly performed there. Thus it is logically to assume, that the stela played a central role in rituals of ancestor worship of the elite. Mayanists such as Patricia McAnany (1995) have pointed out that the veneration of ancestors is a central theme in both ancient and modern Maya culture and that this activity is closely related to important aspects such as site-planning, land ownership and agriculture. 
Finally, as David Stuart (1996) suggested, the religious importance of the stelae can be explained by the fact that they might have served as containers for the "life-force" or "spiritual essence" of the individual depicted. This idea is intriguing, but - as Stuart himself points out - also problematic, for example when we keep in mind that some monuments show not only one but several individuals. Especially defeated foreign rulers, which were often depicted as nude and disgraced prisoners of the local king were certainly not meant to be venerated by later generations. Another problem is posed by the fact that in many cases we have more than one representation of a ruler which was venerated after his death. However, as a cross-cultural comparison in the next section of this paper will illustrate such a concept of a spiritual essence being related to changing places is neither unusual nor unique to the Maya.

Due to the immense importance of the stela-cult among the Maya and the far reaching distribution (both in temporal and spacial terms) of these monuments it seems to be logical to ask, if somewhere in the Maya area elements of this cult might have survived into the colonial period or beyond. In fact, the main argument of this paper is that fragments of the beliefs underlying the Classic Maya stela-cult survived in a modified form in the Highlands of Guatemala up to the arrival of the Spaniards. Furthermore I argued, that some of these religious concepts continue to play a role in contemporary Maya religion. However, due to the dramatic transformations of Maya culture in the $20^{\text {th }}$ century and a current trend in some Maya communities to revitalize pre-colonial religious practices (Frühsorge, 2010), any suggestion of a direct cultural continuity has to be made very carefully and in consideration of the historical developments in between.

\section{Cross-Cultural and Temporal Comparison}

With Stuart's seminal paper "Kings of Stone" (1996) as a point of departure there were two inspirations for me to write this paper:

The first one was a visit to Polynesia in 2009. Similarly iconic as the stela for the ancient Maya are the famous stone statues of Easter Island which are known under their local name as moai. What fascinated me most about these monuments is the fact that despite their impressive size not only the statues but rather the platforms on which they stand are highly significant in cultural terms (figure 2). Many of these platforms, which were used as places to perform ceremonies and as burials grounds, actually predate the moai and some of them were still used when the production of these statues had already been abandoned. In other words the moai were merely decoration, while the platforms turned out to be the really important part of the arrangement. In fact similar platforms (without the monumental statues) are known as marae and can be found all over Polynesia from New Zealand over Tahiti to Hawaii. For the ancient Polynesian these platforms were charged with mana, the spiritual power of the ancestors. Some of the 
stones used in the construction symbolized particular ancestors and when a new marea had to be built one of these stones was moved there, to transfer some of its power to the new place (Wallin, 1993). This example of the Polynesian mana might serve us as a useful intercultural comparison with the stela-cult of the Maya. As the example illustrates we should take caution not to be mislead by the physical size or the visual attraction of an object when we speculate about its religious importance. In other words, the artistically most impressive image of a ruler on a stela was not necessarily more important in terms of ancestor worship then for example a much smaller and uncarved stone erected for the same purpose. The concept of the mana also illustrates that the spiritual essence supposed to be resting in the stela was not necessarily permanently and entirely bound to one place but could rather be removed or circulated between different places. In fact, such an idea of a person's life force being transferred or connected to different stone objects is documented in both colonial documents and ethnographic descriptions discussed below.

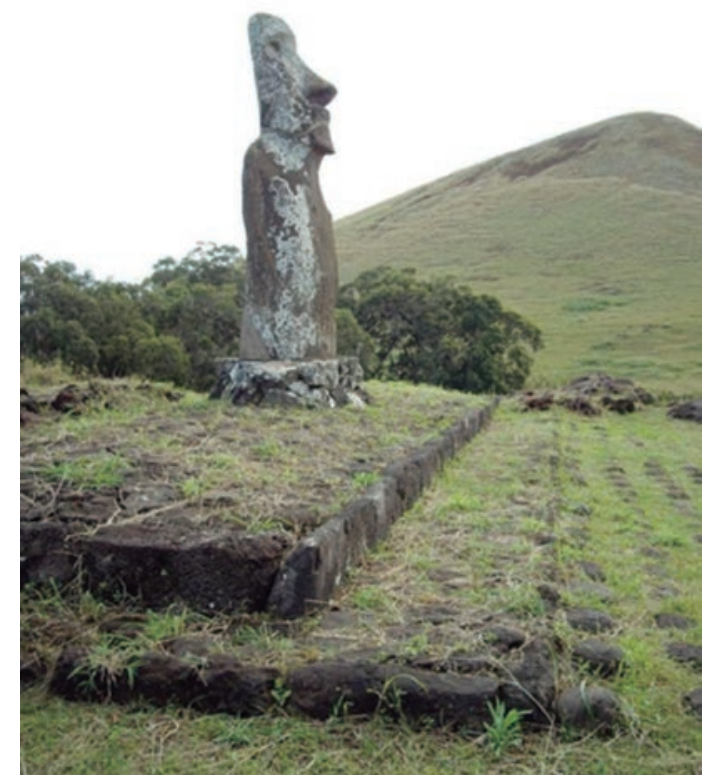

FIGURE 2. Moai on Plattform, Easter Island (Chile)

My second inspiration came from an article "The Stela as a Cultural Symbol" by Joyce Christie (2005) published in the journal Ancient Mesoamerica. She argued that the crosses in modern Maya communities are in fact a survival of the stelacult of the ancient Maya. Although I find this idea intriguing and I agree with many of her conclusions, her approach remains problematic, because she mixed ethnographic descriptions from different places rather uncritically. This turns out 
to be problematic, because crosses among the modern Yukatec Maya have a remarkably different meaning in comparison to crosses in Chiapas or Guatemala. While Christie's direct comparison of Classic and modern Maya culture turns out to be thought-provoking, her failure to distinguish regional variations and to ignore more recent historical developments weakens her argument. To take up and elaborate on her ideas I will concentrate in this paper on just one region, the Highlands of Guatemala and instead of suggesting a direct continuity I will point to a series of historical transformation stretching from the Postclassic to the present.

\section{Burials in the Late Postclassic Maya Highlands}

A good point of departure for the following discussion is a type of royal burial ritual of the Late Postclassic that was performed in the Verapaz region. This ceremony was documented by Fray Bartolomé de Las Casas who worked as a missionary in this area. First of all he reports that that whenever possible a precious stone was used to catch the last breathe of the dying ruler, so that his "soul" could be transferred into the object. These stones containing the spiritual essence of the deceased kings were guarded by high ranking officials and became objects of worship and sacrifices.

Cuando quiera pues que algún señor moría, tenían aparejada una piedra preciosa que ponían a la boca cuando quería expirar, en la cual creían que le tomaban el ánima, y en expirando, con ella muy livianamente le refregaban el rostro. El tomalle aquel resuello, ánima o espíritu, y hacer aquella cerimonia y guardar la dicha piedra, era por sí un principal oficio, y no lo tenía sino una persona de las más principales del pueblo o de la casa del rey, al cual tenían todos en gran reverencia, porque le era estimada por cosa divina, y así lo nombraron hombre de Dios, como si dijeran que aquel hombre se había trasladado a los dioses hecho ya divino. Por esta errada consideración ofrecían a estas piedras en ciertos tiempos sacrificios (Las Casas, 1958: 525).

Las Casas also explains that this practice was widespread even among common people, who used less valuable stones (1958: 527). Then he goes on to describe how the body and the tombs were prepared etc. Finally after the burial has taken place, an altar was built over the grave where ceremonies are performed on a regular basis: "Después encima de la sepultura hacían un altarito [altarcito] de obra de un codo de alto, de cal y piedra, mui bien blanqueado, en el cual quemaban muy ordinariamente inciencio [sic] y ofrecían otros sacrificios" (ibid.).

That this kind of burial practice was not unique to the Verapaz is confirmed by other sources. About one and a half century later Fuentes y Guzmán describes a similar ritual from the Kaqchikel-Maya. There are some minor differences in his description, which we have to take as regional variations. But he also adds an 
important piece of information. Instead of an altar he refers to an image of the ruler placed on top of the burial mound, which was also worshipped like a god.

... y luego cubrían de tierra toda la fosa. Sobre ella levantaban un cerrillo, más o menos alto según la calidad del difunto, y este se fabricaba de piedra y lodo: de que se ven infinitos de todas las llanuras, de estos excelentes y fecundícimos valles, que llaman cues. Fenecida esta función, con grandes ceremonias de cantos muy funestos, tenían labrada una estatua pequeña ó grande del señor que allí enterraban; la cual, con otra tropa de ceremonias ridículas y cansadas por su prolongación, la colocaban con grande veneración en la cima y cúpula de aquel cerrillo, y allí le ofrendaban flores, copal y otros cortezas aromáticas; sacrificándole algunas aves, conejos y tepezquintes: así porque esta ofrenda servía de derechos para la congrua de los Papaces, como porque aquel quedaba por sitio sagrado desde aquel día. En esta forma, si era de rey ó señor natural, el enterramiento era como adoratorio, porque aquella estatua le atribuían deidad; discurriendo de como los había gobernado en vida, cuidaría en muerte de sus conveniencias y buenos temporales (Fuentes y Guzmán, 1970: 254).

Unfortunately we have no archeological evidence from this area which would confirm this description. Certainly most of the statues mentioned by Fuentes y Guzmán were destroyed after the Spanish Conquest by the missionaries. However there are is a small number of images which survived in the communities and which as are still venerated today. The best-know example is the famous Pascual Abaj from Chichicastenango. However, the state of preservation of these objects is generally so poor that we cannot identify any particular iconographic attribute which would allow us to date them or to relate them to a burial context. So this relation remains rather speculative.

\section{Mojones and Land Titles}

In contrast to the small number of anthropomorphic images which survived in the Highlands of Guatemala, there is another type of stone artifacts which can be found in large quantities in every community museum. These objects are commonly known as "Mushroom Stones" and there are several ideas about their original meaning. Most frequently they are interpreted either as phallic symbols or as representations of hallucinogenic mushrooms (Borhegyi, 1961). Due to the quantity of these objects and the fact that they appear in a variety of different forms, sizes and archaeological contexts, it is very likely that different meanings have been attached to them at different times and in different places. One particular interpretation deserves a more detailed discussion, not only due to its relevance to the topic of this paper but also because it was expressed by a modern Maya and thus a descendant of the people who carved these stones. When I was doing ethnographic fieldwork in the Kaqchikel community of Tecpán in 2004, I came across a community museum with a small collection of these objects, which had been found by local farmers in their fields. 
When I discussed the meaning of these objects with the owner of the museum, a cultural activist who calls himself Pakal B'alam, he drastically rejected any sexual or drug-related interpretation and insisted that these were mojones of Ancients. He explained that these stones had been placed by his ancestors for example to divide the plots of land cultivated by different families or to mark the boundaries of communal land.

In fact lists of mojones are an important part of the colonial documents of various communities in the area and their location is often described in detail either in relation to settlements or to certain natural features such as rivers or mountains (Maxwell and Hill, 2006; Recinos, 1957). The importance of these documents and the mojones has to be understood in the historical context of the middle and late colonial period when the Maya population started to recover and lesser agricultural land remained available. In this time not only Maya and Spaniards but also different Indigenous communities were engaged in a variety of land conflicts. In this time land-titles granted by the Spanish Crown as well as historical documents describing the precolonial possessions of a certain lineage became so important that they were guarded by the religious authorities of the communities and treated like sacred objects (Patch, 2002: 93, 101). In this context the demarcation of the boundary of the community's territory became a very important act. It is very likely that whenever a new mojon had to be placed, oral traditions were cited to legitimize this act. In some cases traditional rituals might have been performed, to present the boundaries as part of a divine order, as it had been done in pre-Hispanic times. For example in the Titulo de Sacapulas (Acuña, 1969) it is mentioned that the mojones of the community were originally placed in pre-Hispanic times by a Nawal (patron deity) who was also the leader of the first generation of settlers, who migrated into the area. According to this document the Nawal had certain supernatural powers including the ability to fly, which allowed him to places the mojones right on top of the mountains.

This relationship between ritual and boundary protection can still be observed in Highland Maya communities up to the present day. For example in Todos Santos Cuchumatán or San Mateo Ixtatán colonial land documents are still kept in special chests (known as ordenanza, cajonado or caja real) and guarded by highranking members of the religious hierarchies (figure 3). Up to the mid $20^{\text {th }}$ century ordinary people were not allowed to open these chests and the documents were only exhibited on special rituals occasions (Deuss, 2006; Oakes, 1951). Due to this secrecy surrounding these texts (which had guaranteed the existence of the communities for centuries), they finally became objects of veneration themselves. Even today, and despite the fact that the colonial documents have no legal value anymore, the chests are still the focus of major ritual activities and are believed to serve the protection of the community. Even new legends about the enduring magical powers of these objects emerge from time to time. For example an informant from San Mateo Ixtatán explained that in the 1980s all men of the community was forced by the army to fight the Guerilla who operated in this 
area. So the entire community started to pray in front of the sacred chest and finally it demonstrated its power: The Guerrilleros in the mountains got scared and paralyzed in terror so that they could easily be killed by the people of San Mateo.

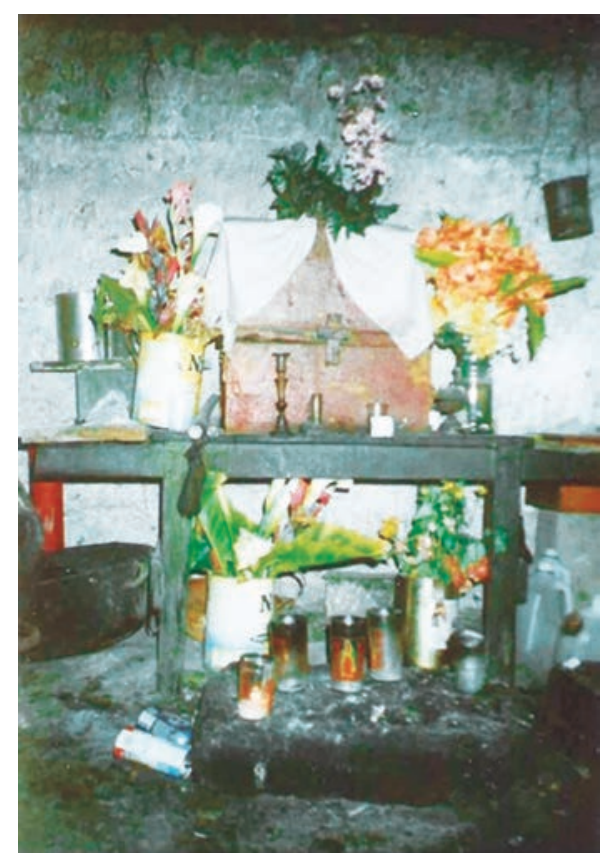

Figure 3. Caja real in Todos Santos Cuchumatán (Guatemala)

\section{Sacred Territories, Sites of Memory}

Apart from the rituals surrounding the sacred chests community boundaries are also marked and protected through short pilgrimages of religious dignitaries which usually include sacred sites on four mountains surrounding the community. These mountains symbolize both the cardinal directions in the traditional world-view and the boundaries of the sacred territory of the community. Each of these places is considered the dwelling place of a deity or protector spirit which is venerated and nourished by the members of the religious hierarchies through prayers and sacrifices. In some cases the location of these altars representing the boundaries are also defined by deep historical memories, as the case of San Mateo Ixtatán illustrates (figure 4): Here the eastern boundary marker is located just a few hundred meters away from the town center, in an archeological site locally known as El Calvario or Wajxaklajun while the other sites are on remote mountain tops several kilometers away such as Cerro Bobi to the south. This unusual location and the resulting asymmetry of the sacred territory appear puzzling 
at first sight. However, in the valley beyond this eastern altar there is another archaeological site, Yax B'atz', which according to oral traditions was once inhabited by people belonging to another "tribe". It is logical that such a place which had been the site or origin of strangers and which probably still remain inhabited by the spirits of their ancestors cannot be part of the communities own sacred territory (Frühsorge and Wölfel, 2009; Wölfel and Frühsorge, 2008).

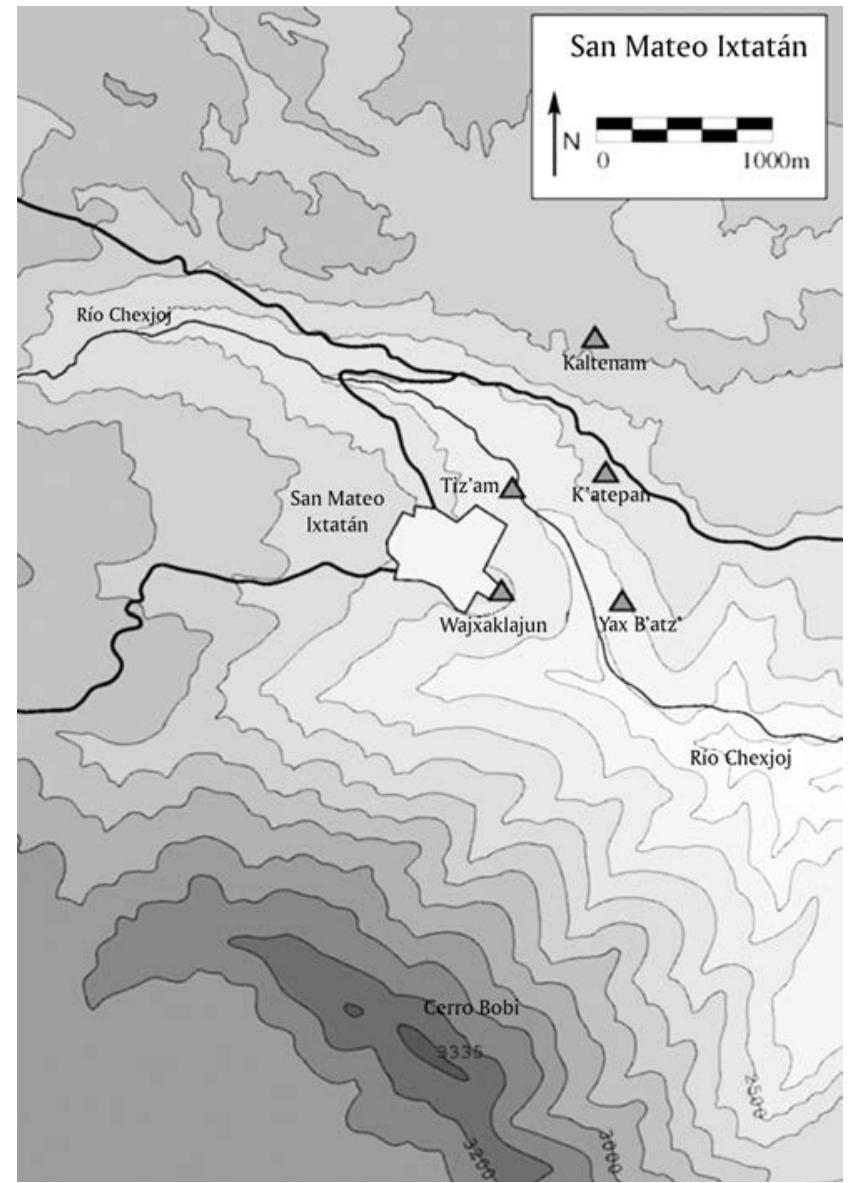

FiguRE 4. Map of San Mateo Ixtatán with archaeological sites (Drawing by Ulrich Wölfel)

Apart from these oral traditions, the altars represent also in a much broader sense sites of memory, because all the important events in the community are communicated to the gods through prayers in these places. Barbara Tedlock (1992) cites a Maya priest from Momostenango, who compared these altars to history books where all the important incidents of the community are inscribed. Tedlock also explains that many of the altars are dedicated to specific lineages 
and that they serve as places of ancestor worship (ibid.). So just like the stelae of the Classic Maya, the contemporary altars are both markers of sacred sites and sites of memory.

\section{Altars as representation of time and power}

Another parallel between the modern altar and the ancient stela is their relationship to the concepts of time and the calendar. In fact the 260-day calendar survived in different communities in Guatemala into the present and the cycles defined by the numbers 1-13 combined with the 20 Day Lords continue to shape ritual life. For example some altars are dedicated to individual Day Lord and others are just visited on specific dates (Tedlock, 1992; Deuss, 2006). In any event, from the point of view of a modern Maya shaman the sacred landscape of the communities is not only defined in a spacial sense but also in a temporal one with specific dates being linked to specific places. In this context the altars - just like the stelae - can be considered not only as representations but even as embodiments of time itself (figure 5).

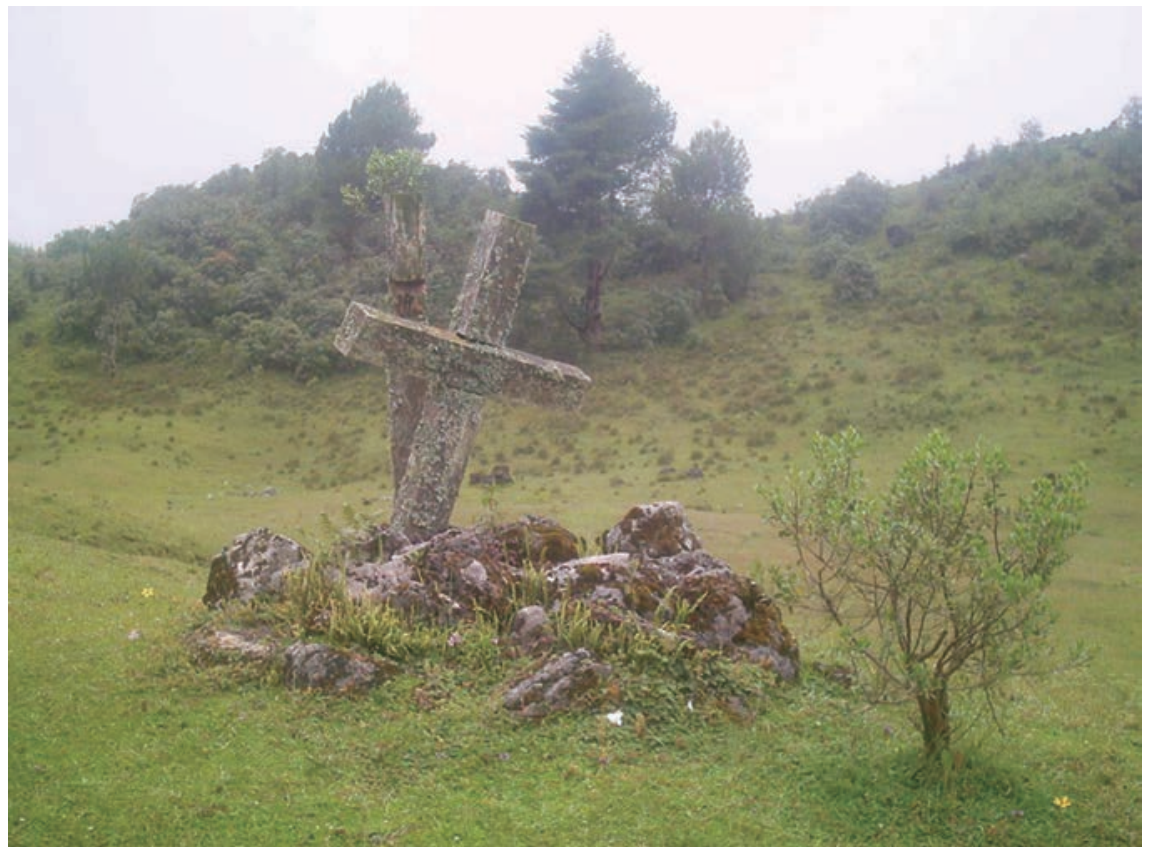

FIGURE 5. Altar in the mountains south of San Mateo Ixtatán

Another aspect linking ancient stelae and modern altars is their representation of power. However, in this case the parallels are rather indirect. While the stelae 
served to represent (and to create) political power, contemporary sites are mostly linked to economic power. A lot of people still believe that prosperity, either in terms of a good harvest or successful business is not entirely man-made but depends on divine support. To acquire this support shamans are hired which in turn perform rituals in specific sacred places associated with prosperity. There is for examples a cave (or more correctly a rock shelter) overlooking Lake Atitlán known as Nimajay or Cueva de las Brujas. This particular place is very much associated with prosperity which is also reflected by its additional Spanish name El Banco del Mundo. The place is visited not only by local shamans and their customers but also by people from more distant places such as Chichicastenango. The cave is currently accessible to everyone and any shaman who feels capable able to communicate with the Lord of this site may use it (Frühsorge, in press a). This is of course a relatively recent development. Up to the mid of the $20^{\text {th }}$ century places like this were guarded by the members of local religious hierarchies who would have either prevented strangers to perform rituals at all or would have asked for a ritual payment of tribute. In any event, due to the assumed necessity to perform these rituals as a prerequisite to become wealthy, sacred sites become important resources both in a religious and in economic terms for the visitor and local people. I believe that this idea dates back to pre-Hispanic times and I agree with scholars how argue, that specific sacred site of the Classic Maya such as caves attracted many pilgrims who in turn made a considerable contributed to the local economy (Colas, 2010; Prufer and Brady, 2005).

Of course this economic function is just one aspect of the sacred geography of the modern Maya. There are also sites specifically dedicated for other purposes such as making prophecies, curing illnesses or even "negative" sites where harmful spells can be casted against an enemy. However even this classification is rather artificial because most sacred sites I am aware of are actually used for more than one purpose even if there is a general agreement that their primary function is a different one. In fact we always have to keep in mind that Maya spirituality (in contrast to Christianity) is not based on a canonized set of beliefs but that there may be important variations from one community or even one shaman to another. At the same time we have good reasons to believe that Ancient Maya religion varied in a same fashion from site to site or from time to time (Friihsorge, in press b).

\section{Camahuil and Sotch}

It has to be admitted that the ethnographic examples cited above appear to be based on pre-Hispanic beliefs which gradually changed over time. However there are two examples which might turn out to be more direct continuities of the ancient stela-cult and the Postclassic mortuary rituals. As I have suggested above, the supposed function of the stelae as containers of the spiritual essence of deceased rulers continued in the Highlands in as burial practice involving a portable stone. 
And indeed, the concept of a stone which contains ancestral powers or which is related to the life-force of an individual does exist in contemporary Maya religion as well. There are actually two cases worth to be examined more closely:

The first example are small anthropomorphic stone images of pre-Hispanic origin, which are frequently found in possession of shamans, who either keep them on their domestic altars or in sacred bundles. In fact only few of these figurines were actually uncovered in archaeological excavations, although a large number of them can be found in museums and private collections all over the world (figure 6). This apparent contradiction is easily explained by the fact that the Maya themselves have collected them for a long time. Consequently the majority of these objects did not remain in the ground but circulated in the communities and were inherited from one generation to the next.

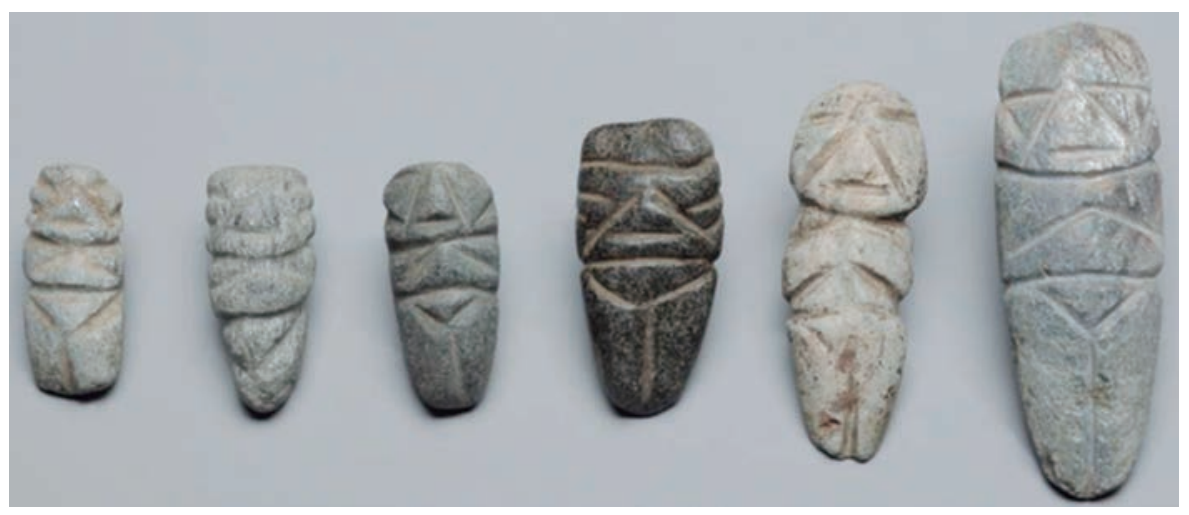

FIgURE 6. Collection of camahuiles (C) Museum für Völkerkunde, Hamburg

The K'iche' refer to them as alxic or camahuil and they are usually believed to represent ancestors. They serve as "little helpers" for examples in curing rituals. In some cases camahuiles are also acquired by parents of a newborn child, because they are supposed to guarantee a long life (Ciudad, 1986; Schultze-Jena, 1931: 22-24). When I was doing fieldwork in the community of Todos Santos in 2006 I came across a similar tradition among the Mam-Maya as well. Here the father of the family I was staying in, related to me that according to the traditional beliefsystem when a child is very ill, the parents are advised by a shaman to place a stone (a natural, uncarved one) in a specific place somewhere in nature for example close to a spring or a river. As long as the stone remains there the child will be fine. Therefore the location is usually kept as a secret. This type of stone is called sotch in Mam. The parallels to the cult of the camahuiles among the K'iche are obvious in this case and seem to indicate a common origin. Another interesting aspect is that my informant described the placement of the stone in agricultural terms, for example when he talked about "planting" or "sowing" the stone or in Spanish 
"sembrar el sotch". This of course reminds us of similar agricultural metaphors in Classic Maya epigraphy and iconography.

\section{Conclusions}

The main argument of this paper has been that certain aspects of the Classic Maya stela-cult can be traced in modified forms in beliefs and rituals of the Highland Maya from the Postclassic and Colonial period into the present. In contrast to other authors who compare archaeological and ethnographic evidence directly to each other, I argue that the search for cases of such a cultural survival requires more than such a simple comparison. I believe that cultural continuity has to be understood as a series of historical transformations and that we must analyze evidence from different time periods to see if such a survival was possible and plausible in the first place. In short, only by taking the whole historical process into account, credibility can be granted to any claim of cultural continuity. Furthermore we have to keep in mind that cultural transformations did not only take place after the arrival of the Spaniards. In the case of the stela-cult of the Classic Maya I have argued that in the Highlands of Guatemala and by the Late Postclassic two particular aspects of the original cult, ancestor worship and the belief of a life-essence being transferred into a stone, were integrated into burial ceremonies but split up into different regional variants, one featuring a portable stone the other one a stone statue erected over the grave. After the Spanish invasion, Maya religion underwent dramatic changes, and with the arrival of the missionaries especially the worship of the large stone images had to be abandoned in most cases. Ceremonies involving portable stones in contrast could survive much easier. However after centuries of clandestine practice and oral transmission these beliefs have been transformed into different regional variants, which no longer formed part of a burial ceremony but focus instead on ancestral powers and the life-force of living persons. Furthermore I have argued that ancient concepts of a sacred geography and the religious legitimization of political and economic power are still reflected in modern rituals and beliefs. However, I have to admit that these ideas are rather general and were never restricted to the stela-cult in particular. So this connection remains just a suggestion. As it is generally the case with issues of cultural continuity, a lot can be speculated but nothing can be proven.

This is especially true when we keep in mind that making a claim of cultural continuity is getting more and more difficult today. Ultimately the modern Maya have started to reclaim their ancient heritage both in cultural and religious terms (figure 7). It is not my intention to challenge the legitimacy of their claims or the related political and cultural demands. On the contrary, I believe that a dialogue between archaeologists and modern Maya can be fruitful for both sides and in many different ways. However, from the perspective of a historian and an 
ethnographer it is important to note, that the modern Maya do have access to archaeological literature and even in remote areas archaeologically generated knowledge penetrates the communities either through the participation of community members in archaeological excavations or through informal channels of communication not obvious to an outsider. Furthermore (and especially in the case of Guatemala) some communities use this knowledge, to enhance their oral tradition or even to revitalize certain ceremonies which had been abandoned long ago (Frühsorge, 2010). Consequently we can never be sure how ancient a "traditional" ceremony we observe today really is. Thus we have to be even more critical in our search for cases of cultural continuity and can rely even less on simple comparison of pre-Hispanic and modern evidence. Ultimately only the combination of archaeological, epigraphy, ethnohistoric and ethnographic date can help us to better understand both the continuities and the transformations that have always shaped Maya culture.

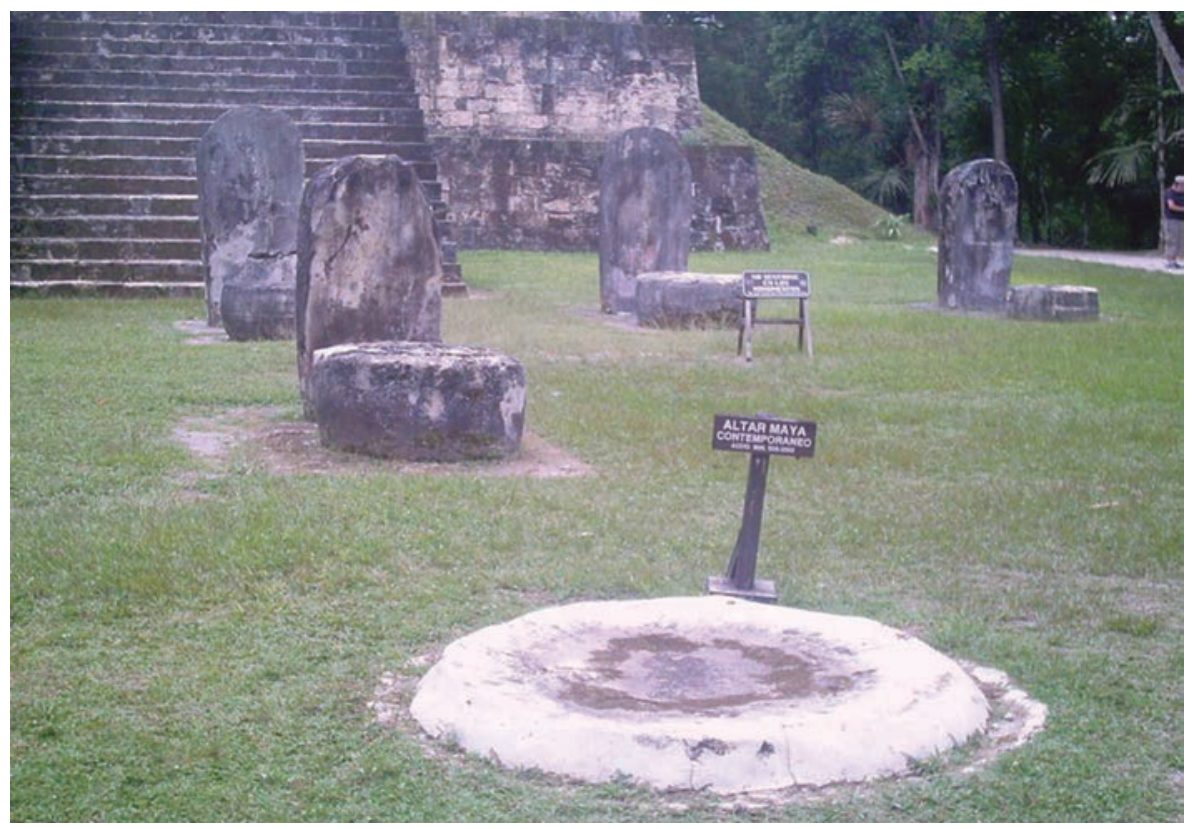

FIGURE 7. Modern altar among ancient stelae, Tikal 


\section{REFERENCES}

Acuña, René

1969 "Título de los señores de Sacapulas”, Folklore Americas, 28 (2): 1-44.

Borhegyi, Stephan F.

1961 "Miniature Mushroom Stones from Guatemala", American Antiquity, 26 (4): 498-504.

Ciudad Ruiz, Andrés

1986 "El culto de los caseríos del área quiché: los camahuiles”, Los mayas de los tiempos tardíos, pp. 63-81, Miguel Rivera and Andrés Ciudad (eds.). Madrid: Sociedad Española de Estudios Mayas.

Colas, Piere Robert

2010 "Die Höhle als kulturelles Symbol bei den klassischen Maya”, Götter, Gräber und Globalisierung: Indianisches Leben in Mesoamerika. 40 Jahre Alt-/ Mesoamerikanistik an der Universität Hamburg, pp. 45-68, Lars Frühsorge, Armin Hinz, Annette Kern and Ulrich Wölfel (eds.). Hamburg: Verlag Dr. Kovač.

Christie, Jessica Joyce

2005 "The Stela as a Cultural Symbol in Classic and Contemporary Maya Societies", Ancient Mesoamerica, 16: 277-89.

Deuss, Krystyna

2006 Shamans, Witches and Maya Priests: Native Religion and Ritual. in Highland Guatemala. London: The Guatemalan Maya Center.

Früihsorge, Lars

2010 Archäologisches Kulturerbe, lokale Erinnerungskultur und jugendliches Geschichtsbewusstsein bei den Maya: Eine historische und ethnographische Untersuchung indigener Interpretationen der vorspanischen Zeit, der spanischen Invasion und des Bürgerkriegs in Guatemala. Hamburg: Verlag Dr. Kovač.

In press a "Zur Ethnohistorie und Ethnographie von Höhlenritualen der Maya", Maya Culture: Identity, Language and History; A Celebration of the Life and Work of Pierre Robert Colas, Frauke Sachse and Christophe Helmke (eds.). Markt Schwaben: Verlag Anton Saurwein.

In press b "Unwrapping the Sacred Bundle: Maya Deities in the Context of Comparative Ethnohistoric and Ethnographic Sources", The Maya in a Mesoamerican Context: Comparative Approaches to Maya Studies, Christophe Helmke and Jesper Nielsen (eds.). Markt Schwaben: Verlag Anton Saurwein.

Frühsorge, Lars and Ulrich Wölfel

2009 “Salt, Sites, and 'Mythology': Cultural Memory in San Mateo Ixtatán (Huehuetenango, Guatemala) from Pre-Hispanic to Modern Times", The Maya and their Sacred Narratives: Text and Context of Maya Mythologies, Proceedings of the 12th European Maya Conference, Geneva, December 7-8, 2007, pp. 157- 
173, Genviève Le Fort, Raphaël Gardiol, Sebastian Matteo and Christophe Helmke (eds.). Markt Schwaben: Verlag Anton Saurwein.

Fuentes y Guzmán, Francisco Antonio de

1970 Obras históricas de don Francisco Antonio de Fuentes y Guzmán, vol. II, Carmelo Sáenz de Santa María (ed.). Madrid: Ediciones Atlas.

Landa, Diego de

1985 Relación de las cosas de Yucatán, Miguel Rivera Dorado (ed.). Madrid: Historia 16.

Las Casas, Bartolomé de

1958 Apologética Historia Sumaria: cuanto a las cualidades, disposición, descripción, cielo y suelo destas tierras, y condiciones naturales, policías, repúblicas, manera de vivir e costumbres de las gentes destas Indias occidentales y meridionales cuyo imperio soberano pertenece a los Reyes de Castilla. Juan Pérez de Tudela (ed.). Madrid: Editorial Atlas.

Maler, Teobert

1997 Península de Yucatán. Hans Prem (ed.). Berlin: Mann.

Martin, Simon and Nikolai Grube

2008 Chronicle of the Maya Kings and Queens: Deciphering the Dynasties of the Ancient Maya. London: Thames and Hudson.

Maxwell, Judith and Robert M. Hill

2006 Kaqchikel Chronicles: The Definitive Edition. Austin: University of Texas Press.

McAnany, Patricia

1995 Living with the Ancestors: Kinship and Kingship in Ancient Maya Society. Austin: University of Texas Press.

Oakes, Maud

1951 The Two Crosses of Todos Santos: Survivals of Mayan Religious Ritual. New York: Pantheon Books.

Patch, Robert W.

2002 Maya Revolt and Revolution in the Eighteenth Century. New York: Sharpe.

Prufer, Keith Malcolm and James E. Brady

2005 Stone Houses and Earth Lords: Maya Religion in the Cave Context. Boulder: University Press of Colorado.

Recinos, Adrián

1957 Crónicas indígenas de Guatemala. Guatemala: Imprenta Universitaria.

Schultze-Jena, Leonhard

1931 Indiana: Leben, Glaube und Sprache der Quiché von Guatemala. Jena: Gustav Fischer. 
Stephens, John L.

1969 Incidents of Travel in Central America, Chiapas and Yucatán, 2 Bände. New York: Dover Publications.

Stuart, David

1996 "Kings of Stone: A Consideration of Ancient Stelae in Maya Ritual and Representation", Res, 29/30: 148-171.

Tedlock, Barbara

1992 Time and the Highland Maya. Albuquerque: University of New Mexico Press.

Wallin, Paul

1993 Ceremonial. Stone Structures: The Archaeology and Ethnohistory of the Marae Complex in the Society Islands, French Polynesia. Uppsala: Societies Archaeologica Upsaliensis.

Wölfel, Ulrich and Lars Frühsorge

2008 "Archaeological Sites Near San Mateo Ixtatán: Hints at Ethnic Plurality", Mexicon, 30 (4): 86-93. 